Новічкова Т.П.

кандидат технічних наук, доцент кафредра готельно-ресторанного бізнесу

E-mail: tamarakoled@gmail.com

ORCID ID: 0000-0001-6133-9882

\author{
Новічков В.К. \\ кандидат географрічних наук, доцент \\ кафедра готельно-ресторанного бізнесу \\ Одеська національна академія харчових технологій \\ вул. Канатна 112, м. Одеса, Україна, 65039 \\ E-mail: vicnov@ukr.net \\ ORCID ID: 0000-0001-9720-8163
}

Лебеденко Т.є.

доктор технічних наук, професор

кафедра готельно-ресторанного бізнесу

mail: tatyanalebedenko27@gmail.com

ORCID ID: 0000-0001-8385-4674

\title{
ІМПЛЕМЕНТАЦІЯ СЕРВІСНИХ ІННОВАЦІЙ В ОРГАНІЗАЦІЮ ДІЯЛЬНОСТІ ЗАКЛАДІВ РЕСТОРАННОГО ГОСПОДАРСТВА
}

Інноваційна діяльність спрямована на створення нового або зміну наявного продукту, на вдосконалювання наявних послуг, освоєння нових ринків, впровадження передових інформаційних технологій і сучасних фоорм організаційно-управлінської діяльності. Вони стають визначальними чинниками для конкурентоспроможності підприємств та активізації обмінів з іншими секторами економіки, з ним пов'язаними. Проведене дослідження дало змогу проаналізувати діяльність ресторану «Щастя Пале Рояль», визначити його головних конкурентів та розробити концепцію розвитку ресторану. Для цього було запропоновано ввести професію сомельє (винного та хлібного. Складено концептуальне меню хлібобулочних виробів, яке має різні види хліба, що пасуватимуть для різних страв в основному меню закладу. Реалізація зазначених напрямків розвитку інноваційної діяльності створить умови для розширення переліку надаваних послуг, посилить конкурентні позиції та переваги підприємств.

Ключові слова: сервіс, інновації, ресторан, обслуговування, сомельє, конкуренція, хлібний сомельє.

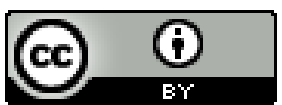

This work is licensed under a Creative Commons Attribution 4.0 International License http://creativecommons.org/licenses/by/4.0/
Постановка проблеми та її зв'язок з важливими науковими та практичними завданнями. Індустрія гостинності та пов'язаний 3 нею бізнес $\epsilon$ важливою складовою національної економіки держави. Розвиток ресторанного бізнесу напряму залежить від соціально-економічного стану країни і визначаються національними рисами населення.

Ресторанний бізнес - це інтегрована сфера підприємницької діяльності, пов'язана з організацією виробництва та управлінням ресторану, спрямована на задоволення потреб населення здоровою та смачною їжею, сервісними послугами, та отримання прибутку. Сьогодні ресторанний сервіс знаходиться в непростих умовах. Основним джерелом добробуту підприємства ресторанного бізнесу є клієнти, які користуються послугами, які надаються. Тому в умовах конкуренції робота підприємства повинна бути організована таким чином, щоб клієнти віддали перевагу саме йому серед інших. Якість обслуговування, розглядається як сукупність характеристик процесу і умов обслуговування, які забезпечують задоволення встановлених або пропонованих потреб споживача.

Аналіз останніх досліджень і публікацій. Питання загальних проблем розвитку ресторанного бізнесу в Україні розглядаються у наукових працях В.
Карсеніна, Т. Ткаченко. Г. Пятницька розглядає ресторанні (сервісні) інноваційні технології, Т. Литвиненко у своїх роботах досліджує новітні технології обслуговування клієнтів. Питання ресторанних послуг, що пов'язані з доставкою готових страв споживачам, розглядає О. Бреус. Важливим інноваційним проявом обслуговування споживачів у закладах громадського харчування $\epsilon$ впровадження нової спеціальності сомельє винний та хлібний. Слід зазначити, що в існуючій науковій літературі означена проблематика висвітлена недостатньо, тому потребує аналізу на засадах креативного підходу.

Формулювання цілей дослідження. Мета статті - узагальнення можливих сервісних інновацій й охарактеризувати напрями їх використання в діяльності закладів ресторанного господарства.

Виклад основних результатів та їх обгрунтування. Розвиток сфери послуг та підвищення іiі ефективності задоволення потреб суспільства безпосередньо пов'язані з інноваціями.

Закон України «Про інноваційну діяльність» визначає «інновації - новостворені (застосовані) i (або) вдосконалені конкурентоздатні технології, продукція або послуги, а також організаційно-технічні рішення виробничого, адміністративного, комерцій- 
ного або іншого характеру, що істотно поліпшують структуру та якість виробництва і (або) соціальної сфери» [1]. У Міжнародному стандарті «Керівництво Осло», це поняття трактується як «ведення у вживання будь-якого нового або значно покращеного продукту (товару або послуги) або процесу, нового методу маркетингу або нового організаційного методу у діловій практиці, організації робочих місць або внутрішніх зв'язках» [2].

В. Іванова зазначає, що «направленість інновацій на результат виникає внаслідок вкладення капіталу в нову техніку або технологію, у нові форми організації виробництва праці, обслуговування і управління, аналізу» [3]. О. Аврамова розглядаючи інновацію як результат, наголошує про появу нового інтелектуального продукту, який вводиться в ринковий обіг (комерціалізується) [4]. У практичній діяльності інновація $є$ корисна імітація, яка полягає в розвитку та реалізації чужих ідей. У своїх працях П. Друкер називав таку імітацію творчої, а людей, що займаються такою діяльністю - творчими імітаторами [5]. Погляди Друкера схожі з підходом Т. Левітта, який вважав, що «не у всіх інноваціях є новизна, це, скоріше, імітація» [6].

Представник австрійської економічної школи
Й. Шумпетер ввів у науковий обіг термін «інновація» як нову економічну категорію [7], який розуміє під інновацією або продукт, або виробничий процес, або організацію процесу за умови, що вони є новими i впровадженими.

Аналіз наукових робіт присвячених проблемі теорії інноваційного розвитку, дає змогу виявити та виділити ще одну групу науковців, які присвятили свої праці встановленню та структуризації ключових ознак дефініції інновація. Так, Антонюк Л. під інновацією розуміє «нове явище, новаторство або будьяку зміну, яка вноситься суб'єктом господарювання у власну діяльність із метою підвищення своєї конкурентоспроможності, як на внутрішньому, так і на зовнішньому ринках» [8].

В умовах нестабільного, кризового економічного стану та пандемією короновірусу для підприємств ресторанного бізнесу постає питання відходу від традиційних та пошук нових методів обслуговування. Інновації в ресторанному господарстві можна віднести до виробничих (виробництво продуктів харчування) та невиробничі (надання послуг з організації харчування та не пов'язаних з цим процесом послуг). Характеристика інноваційних технологій сучасного ресторанного бізнесу наведено в табл. 1.

Таблиця 1

Характеристика інноваційних технологій у соціокультурному просторі сучасного ресторанного бізнесу [9]

\begin{tabular}{|c|c|}
\hline $\begin{array}{l}\text { Назва інноваційної } \\
\text { технології }\end{array}$ & Характеристика \\
\hline Креативні ІТ-технології & $\begin{array}{l}\text { Нові інформаційні технології впроваджують креативні інновації в ресторанний } \\
\text { бізнес. Науково-технічний прогрес пропонує теплан-шоу з інновацією - поряд } 3 \\
\text { робочим місцем кухаря на кухні вмонтована камера, а на моніторах у залі за сто- } \\
\text { ликами за його діями спостерігають відвідувачі. }\end{array}$ \\
\hline Електр & $\begin{array}{l}\text { Нові винаходи від Аррlе стали революційною інновацією в ресторанному бізнесі. } \\
\text { Для відвідувачів візит у ресторан можна порівняти з грою, яка дозволяє: обрати } 3 \\
\text { карти вин закладу вино; підрахувати калорійність тих чи інших страв; під час ви- } \\
\text { бору страв бачити одразу кінцеву суму чека; в очікуванні замовлення пограти в } \\
\text { ігри, скористатися Інтернетом. }\end{array}$ \\
\hline $\begin{array}{l}\text { QR-код і можливості } \\
\text { маркетингу }\end{array}$ & $\begin{array}{l}\text { Винахід QR-коду надав необмежені можливості для он-лайн взаємодії із користу- } \\
\text { вачами. У QR-коді можна запрограмувати всі відомі інновації ресторанного біз- } \\
\text { несу. }\end{array}$ \\
\hline «Мобільний офіціант» & $\begin{array}{l}\text { Ефективний спосіб прийняття замовлення за допомогою бездротових портатив- } \\
\text { них приладів. }\end{array}$ \\
\hline $\begin{array}{l}\text { Шведський стіл на кон- } \\
\text { веєрі }\end{array}$ & $\begin{array}{l}\text { Готові страви 3-під кухонних інструментів на конвеєрі проходять через столики. } \\
\text { Відвідувачі можуть брати з рухомої стрічки все, що подобається. }\end{array}$ \\
\hline «Кобрен» & $\begin{array}{l}\text { «Кобрендинг»- це симбіоз } 2 \text { різних напрямів бізнесу, де гість може не тільки обі- } \\
\text { дати, але й здійснювати власні справи. }\end{array}$ \\
\hline $95 \%$ роботів & $\begin{array}{l}\text { Основну роботу виконують роботи під керівництвом інженерів. Зустрічають клі- } \\
\text { єнтів робошвейцари, готують страви робокухарі, обслуговують відвідувачів ро- } \\
\text { боофіціанти. }\end{array}$ \\
\hline $\begin{array}{l}\text { «̈̈ і плати скільки хо- } \\
\text { чеш» }\end{array}$ & $\begin{array}{l}\text { Практика ведення ресторанного бізнесу, яка базується на відсутності цін на стра- } \\
\text { ви та напої, відвідувачі повинні на власний розсуд сплачувати кошти. }\end{array}$ \\
\hline Усе по одній ціні & $\begin{array}{l}\text { Всі продукти коштують однаково за кілограм. На прилавках розміщені різні стра- } \\
\text { ви і посуд. За бажанням обрані страви, самостійно кладуть на тарілку і відносять } \\
\text { до каси. Тарілку зважують і розраховують згідно з вагою і фіксованою сумою. }\end{array}$ \\
\hline
\end{tabular}

Незважаючи на високий ступінь ризику ведення господарської діяльності та інвестування, низь- кий рівень платоспроможності населення кількість ресторанів постійно зростає. Причина цього явища 
полягає в тому, що у трансформаційний період в країні з'явилися ресторани VIP-класу, основними споживачами послуг, була бізнес-еліта, що складає, за оцінками експертів 2,5 \% населення країни. У структурі закладів ресторанного господарства кафе, закусочні, буфети складають 54 \%, що свідчить про стійкий попит споживачів на продукцію та послуги цих підприємств [10].

За статистичними даними 2019 р. у містах: Києві, Львові, Одесі, Харкові, Запоріжжі та Дніпрі діяло 10989 підприємств сфери харчування. 3 частка кафе і ресторанів складала - $46 \%$, заклади категорії «Fast Food» - 40 \%, бари, паби та нічні клуби - $14 \%$ [10].

Концепція ресторану: «Щастя Пале Рояль»мережа ресторанів для тих, хто розбирається в їжі, піклується про своє здоров'я, подорожує і порівнює. Вони постаралися зібрати найкращі страви різних країн, тому в їхньому меню є страви різних концепцій і національних кухонь, де кожен знайде щось до смаку. Ресторан «Щастя Пале Рояль» на 70 посадкових місць у зимовий період (220 місць у літній період). Торгова зала ресторану знаходиться на першому поверсі старої будівлі, має сучасний інтер'єр, виконаний у сірих тонах. У всій мережі ресторану діє система знижок для постійних гостей закладу від $10 \%$ до $50 \%$, є свій мобільний додаток, де кожен гість закладу може зареєструватися та накопичувати бонуси. Існують акції за дням тижня на певні напої з меню бара. Основними споживачами ресторану «Щастя Пале Рояль» є люди середнього та високого статку, жінки та чоловіки від 25-45 років. Для оцінки конкурентоспроможності підприємства проведено аналіз зовнішніх та внутрішніх переваг відносно конкурентів (дані результату наведено у табл. 2).

Таблиця 2

Оцінка конкурентоспроможності ресторанів *

\begin{tabular}{|l|c|c|c|c|c|}
\hline \multicolumn{1}{|c|}{ Параметри оцінки } & $\begin{array}{c}\text { Ресторан «Щас- } \\
\text { тье Пале Рояль» }\end{array}$ & $\begin{array}{c}\text { Ресторан } \\
\text { «Fanconi» }\end{array}$ & $\begin{array}{c}\text { Ресторан } \\
\text { «Риба» }\end{array}$ & $\begin{array}{c}\text { Pесторан } \\
\text { «Salieri» }\end{array}$ & $\begin{array}{c}\text { Ресторан } \\
\text { «Maman» }\end{array}$ \\
\hline Середній чек & 4 & 2 & 3 & 4 & 5 \\
\hline Асортимент страв у меню & 5 & 5 & 5 & 3 & 4 \\
\hline Дизайн & 4 & 3 & 4 & 4 & 4 \\
\hline Місце розташування & 5 & 5 & 4 & 5 & 5 \\
\hline Якість обслуговування & 4 & 5 & 3 & 5 & 5 \\
\hline Додаткові сервіси & 2 & 3 & & & \\
\hline Загальна кількість балів & $\mathbf{2 4}$ & $\mathbf{2 3}$ & $\mathbf{1 9}$ & $\mathbf{2 1}$ & $\mathbf{2 3}$ \\
\hline
\end{tabular}

*Розроблено авторами

3 поведеного авторами дослідження, щодо удосконалення механізмів конкурентної боротьби, констатовано, підприємства ресторанного господарства не лише займаються пошуком нових сегментів ринку, але й впроваджують інноваційні технології щодо креативної кухні та рецептур, дизайну, використання сучасних інформаційних технологій (Інтернет та Інтранет), обслуговування до яких можна віднести кейтеринг-сервіс тощо [11].

Сомельє (sommelier) - французьке слово, аналогів якого не існує. Згідно з визначенням, запропонованим Ж. Пертюізе, сомельє - це «людина, відповідальна за подачу напоїв у ресторані, що дає поради щодо вибору вин і напоїв, що сервірує їх або стежить за їх подачею клієнту, аж до моменту, коли той покидає зал» [12].

Сомельє - це символ рівня і класу закладу. По суті, це людина, яка перший підходить до столу і задає «настрій трапези». Наявність в ресторані сомельє свідчить про те, що цей заклад високого класу, що надає повний комплекс послуг в сфері ресторанного бізнесу, в якій сомельє може символізувати вищу стадію розвитку [12].

В обов'язки сомельє, як правило, входить складання винної карти і підтримка відповідно до неї запасу вин в ресторані. Сомельє часто буває відповідальним за закупівлю вина або, як мінімум, бере участь в обговоренні замовляються партій. Тому, крім володіння загальною інформацією про вина i їх достоїнства, йому необхідно добре знання ринку. I якщо сомельє бере на себе відповідальність за співвідношення ціни і якості вина, він повинен уважніше ставитися до вибору постачальників. У зв'язку з цим сомельє називають джерелом доданої вартості вина в ресторані.

Сомельє, який працює в ресторанному залі, стає психологом - йому доводиться вгадувати настрій своїх клієнтів, іноді визначати їхній соціальний статус і походження. На думку головного сомельє Франції Жоржа Пертюізе, сомельє зобов'язаний швидко ловити думки клієнта.

Офіційно професія хлібного сомелье 3'явилася в Німеччині в 2015 році (в Академії пекарського ремесла Вайнхайм, з'явився перший курс, присвячений дегустації хліба). Німецька культура споживання хліба найрізноманітніша в світі - налічується більше 3200 сортів випічки. У Німеччині налічується всього 44 представників цієї професії та 2 - в Австрії.

Хлібний сомельє розбирається в випічці так само, як і його відомий колега - у вині. Місія хлібного сомельє - зберегти розмаїття та примножити культуру споживання хліба. У ресторані «Щастя ПалеРояль» невеликий вибір хлібних виробів, а саме, домашній хліб, що подається з оливковою олією, часником та зеленню; житній хліб, висівковий солодовий 
хліб, тостовий хліб, чіабатта. Тому нами пропонується розробити хлібне меню, що буде пасувати до страв, які знаходяться в основному меню закладу.
Основні хлібні вироби, що пропонуються для ресторану «Щастя Пале Рояль» наведено у таблиці 3.

Таблиця 3

Основні хлібні вироби, що пропонуються для ресторану «Щастя Пале Рояль»*

\begin{tabular}{|l|l|l|}
\hline \multicolumn{1}{|c|}{$\begin{array}{c}\text { Назва хлібобулочного } \\
\text { виробу }\end{array}$} & \multicolumn{1}{|c|}{ Характеристика } & \multicolumn{1}{|c|}{ До чого пасує? } \\
\hline Французький багет & $\begin{array}{l}\text { Національний французький хліб з непе- } \\
\text { ревершеною хрумкою скоринкою. }\end{array}$ & $\begin{array}{l}\text { Подають до будь-яких страв, замість } \\
\text { звичайного хліба. }\end{array}$ \\
\hline Гріссіні з сиром & $\begin{array}{l}\text { Iталійські хлібні палички, які дуже тонкі } \\
\text { та хрусткі, з додаванням сиру. }\end{array}$ & $\begin{array}{l}\text { Подають до салатів, сирних тарілок, } \\
\text { крем-супів та паст. }\end{array}$ \\
\hline Булочки з кунжутом & $\begin{array}{l}\text { М’які пшеничні булочки, що присипа- } \\
\text { ються кунжутом зверху. }\end{array}$ & $\begin{array}{l}\text { Подають до будь-яких страв, замість } \\
\text { звичайного хліба. }\end{array}$ \\
\hline $\begin{array}{l}\text { Булочки з насінням } \\
\text { вамич }\end{array}$ & $\begin{array}{l}\text { Дріжджові житні булочки, які присипа- } \\
\text { ються насінням. }\end{array}$ & $\begin{array}{l}\text { Подають до будь-яких страв, замість } \\
\text { звичайного хліба. }\end{array}$ \\
\hline $\begin{array}{l}\text { Крученний багет з оли- } \\
\text { вками }\end{array}$ & $\begin{array}{l}\text { Французький хліб з хрумкою скоринкою, з тра- } \\
\text { ніжним м'якушем та додавання прован- } \\
\text { ських трав. }\end{array}$ & $\begin{array}{l}\text { Можна подавати окремо з оливковою } \\
\text { оліє а також до салатів та закусок, } \\
\text { паст. }\end{array}$ \\
\hline Круассан & та додавання оливок. & $\begin{array}{l}\text { Подають як окрему страву з оливко- } \\
\text { вою олією, а також до закусок, сала- } \\
\text { тів, паст. }\end{array}$ \\
\hline
\end{tabular}

*озроблено авторами

Висновки та перспективи подальших досліджень. Інноваційна діяльність спрямована на створення нового або зміну наявного продукту, на вдосконалювання наявних послуг, освоєння нових ринків, впровадження передових інформаційних технологій i сучасних форм організаційно-управлінської діяльності. Вони стають визначальними чинниками для конкурентоспроможності підприємств та активізації обмінів 3 іншими секторами економіки, 3 ним пов'язаними. Проведене дослідження дало змогу проаналізувати діяльність ресторану «Щастя Пале Ро- яль», визначити його головних конкурентів та розробити концепцію розвитку ресторану. Для цього було запропоновано ввести професію сомельє (винного та хлібного. Складено концептуальне меню хлібобулочних виробів, яке має різні види хліба, що пасуватимуть для різних страв в основному меню закладу. Реалізація зазначених напрямків розвитку інноваційної діяльності створить умови для розширення переліку надаваних послуг, посилить конкурентні позиції та переваги підприємств побутового обслуговування.

\section{Література}

1. Про інноваційну діяльність Закон України: за станом на 05.12.2012 // Верховна Рада України. URL: https://zakon.rada.gov.ua/laws/show/40-15\#Text (дата звернення 12.01.2021).

2. Рекомендации по сбору и анализу данных по инновациях. Oslo manual. 3-е изд. М. 2006. 192 с.

3. Іванова В. В. Дослідження теорії поняття інновації // Економіка Промисловості. 2009. № 47. doi: 10.5860/CHOICE.47-1395. URL: http://archive.nbuv.gov.ua/portal/soc_gum/eprom/2009_47/st_47_13.pdf7 (дата 3вернення 12.01.2021).

4. Аврамова О. С. До проблеми визначення інновації // Актуальні проблеми розвитку українського суспільства. Харків: НТУ «ХПІ». 2011. № 30. 179 с.

5. Про инновации и имитации творческих идей в бизнесе: веб-

сайт. URL: http://www.adme.ru/tvorchestvo-reklama/pro-innovacii-i-imitacii-tvorcheskih-idej-v-biznese-5043 (дата звернення 12.01.2021).

6. Poznanski, K. Innowacje w gospodarce kapitalisty cznej. Warszawa, 1979. 283 p.

$\begin{array}{llllll}\text { 7. Базилевич } & \text { В. } & \text { Д. Неортодаксальная } & \text { теория } & \text { И. } & \text { А. }\end{array}$ pa. URL: http://econbooks.ru/books/part/20291 (дата звернення 12.01.2021).

8. Антонюк Л. Л., Поручник А. М., Савчук В. С. Інновації: теорія, механізм розробки та комерціалізації: монографія. К.: КНЕУ. 2013. 394 с.

9. Завгородня О. С. Додаткові послуги й інновації в соціокультурному просторі // Культура України. 2016. Випуск 52. С. 21-34. 
10. Ресторанне господарство як складова індустрії гостинності: вебсайт. URL: https://pidru4niki.com/14170120/turizm/organizatsiya_protsesu_obslugovuvannya_yogo_materialnotehnichne_zabezpechennya (дата звернення 10.01.2021).

11. Нагернюк Д. В. Основні чинники, що формують конкурентоспроможність підприємств ресторанного господарства. URL: http://www.economy.nayka.com.ua/?op=1\&z=5142 (дата звернення 12.01.2021).

12. Що входить в обов'язки сомельє? веб-сайт. URL: https://genomukr.ru/rizne/23884-shho-vhodit-vobov-jazki-somele.html (дата звернення 12.01.2021).

Стаття надійшла 20.01.2021

Стаття прийнята до друку 3.02.2021

Доступно в мережі Internet 18.04.2021

Novichkova T.

Ph.D., Associate Professor

Department of Hotel and Restaurant Business

E-mail: tamarakoled@gmail.com

ORCID ID: 0000-0001-6133-9882

\section{Lebedenko T.}

Doctor of Technical Sciences, Professor

Department of Hotel and Restaurant Business

E-mail: tatyanalebedenko27@gmail.com

ORCID ID: 0000-0001-8385-4674

\section{Novichkov V.}

Ph.D., Associate Professor

Department of Hotel and Restaurant Business

Odessa National Academy of Food Technologies

Kanatna str., 112, Odesa, Ukraine, 65039

E-mail: vicnov@ukr.net

ORCID ID: 0000-0001-9720-8163

\section{IMPLEMENTATION OF SERVICE INNOVATIONS IN THE ORGANIZATION OF ACTIVITIES OF RESTAURANT ESTABLISHMENTS}

The restaurant business is an integrated area of business activity, related to the organization of production and management of the restaurant, aimed at meeting the needs of the population with healthy and tasty food, services, and making a profit. Today the restaurant service is in difficult conditions. The main source of well-being of the restaurant business are customers who use the services provided. Therefore, in a competitive environment, the work of the enterprise should be organized in such a way that customers prefer it among others. Quality of service is considered as a set of process characteristics and service conditions that ensure the satisfaction of the established or proposed needs of the consumer.

The catering business is an important and most important part of the hospitality industry. Prospects for the restaurant business depend primarily on the economic situation in the country and are determined by national characteristics of the population. The successful operation of restaurants depends on how the institution will be able to attract and retain consumers. The solution of this main task depends on many components, in particular: the menu, cuisine, interior, level of service culture, appearance and behavior of the staff of the establishment, ie the culture of restaurant service in general. The success of the restaurant business is determined by the ability to meet and anticipate the needs and expectations of guests.

The restaurant business, on the one hand, is one of the means of use of highly liquid capital, and on the other - an environment with high competition. The purpose is to generalize possible service innovations and to characterize the directions of their use in the activity of restaurant establishments.

The development of the service sector and the increase of its efficiency in meeting the needs of society are directly related to innovation.

Innovative activity is aimed at creating a new product or changing an existing one, improving existing services, developing new markets, introducing advanced information technologies and modern forms of organizational and managerial activities. They are becoming determinants of the competitiveness of enterprises and the intensification of exchanges with other sectors of the economy related to it. The study made it possible to analyze the activities of the restaurant "Happiness Palais Royal", identify its main competitors and develop a concept for the development of the restaurant. To do this, it was proposed to introduce the profession of sommelier (wine and bread). A conceptual menu of bakery products, which has different types of bread that will suit different dishes in the main menu has been developed. Implementation of these areas of innovation will create the conditions for broadening the list of services, and will strengthen competitive positions and advantages of enterprises.

Key words: service, innovation, restaurant, service, sommelier, competition, bread sommelier. 


\section{References}

1. Pro innovatsiinu diialnist Zakon Ukrainy: za stanom na 05.12.2012. Retrieved March 12, 2021, from https://zakon.rada.gov.ua/laws/show/40-15

2. Oslo manual. (2006). Rekomendatsii po sboru i analizu dannyih po innovatsiyah (3rd ed.).

3. Ivanova, V. V. (2009). Doslidzhennia teorii poniattia innovatsii. Ekonomika Promyslovosti, (47). doi: 10.5860/CHOICE.47-1395 Retrieved January $\quad 12, \quad$ from http://archive.nbuv.gov.ua/portal/soc_gum/eprom/2009_47/st_47_13.pdf7

4. Avramova, O. Ye. (2011). Do problemy vyznachennia innovatsii. Aktualni problemy rozvytku ukrainskoho suspilstva, (30).

5. Pro innovatsii $i$ imitatsii tvorcheskih idey $v$ biznese. Retrieved January 12, 2021, from http://www.adme.ru/tvorchestvo-reklama/pro-innovacii-i-imitacii-tvorcheskih-idej-v-biznese-5043

6. Poznanski, K. (1979). Innowacje w gospodarce kapitalisty cznej. Warszawa.

7. Bazilevich, V. D. Neortodaksalnaya teoriya Y. A. Shumpetera. Retrieved January 12, 2021, from http://econbooks.ru/books/part/20291

8. Antoniuk, L. L., Poruchnyk, A. M., \& Savchuk, V. S. (2013). Innovatsii: teoriia, mekhanizm rozrobky ta komertsializatsii. Kyiv: KNEU.

9. Zavhorodnia, O. Ye. (2016). Dodatkovi posluhy y innovatsii v sotsiokulturnomu prostori. Kultura Ukrainy, (52). 21-34.

10. Restoranne hospodarstvo yak skladova industrii hostynnosti. Retrieved January 10, 2021, from https://pidru4niki.com/14170120/turizm/organizatsiya_protsesu_obslugovuvannya_yogo_materialno-

tehnichne_zabezpechennya

11. Naherniuk, D. V. Osnovni chynnyky, shcho formuiut konkurentospromozhnist pidpryiemstv restorannoho hospodarstva. Retrieved January 12, 2021, from http://www.economy.nayka.com.ua/?op=1\&z=5142

12. Shcho vkhodyt v oboviazky somelie? Retrieved January 12, 2021, from https://genomukr.ru/rizne/23884-shhovhodit-v-obov-jazki-somele.html

Received 20 January 2021

Approved 3 February 2021

Available in Internet 18.04.21

Цитування згідно ДСТУ 8302:2015

Новічкова Т.П., Лебеденко Т.Є., Новічков В.К. Імплементація сервісних інновацій в організацію діяльності закладів ресторанного господарства // Економіка харчової промисловості. 2021. Т.13, вип. 1. С. 69-74.

Cite as APA style citation

Novichkova, T., Lebedenko, T., \& Novichkov, V. (2021). Implementation of service innovations in the organization of activities of restaurant establishments. Food Industry Economics, 13(1), 69-74 